\title{
THE EFFECT OF ASCORBIC ACID TREATMENT ON WHEAT (TRITICUM AESTIVUM L.) SEEDLINGS UNDER DROUGHT STRESS
}

\author{
Khadr, S.A. ; S.M. El-Hamamsy ; H.A. El-khamissi and Z.H. Saad
}

Biochemistry Dep., Faculty of Agric., Al-Azhar Univ., Cairo, Egypt

Key Words: Ascorbic acid, drought stress, chlorophyll, enzymes activity

\begin{abstract}
Three Egyptian wheat (Shanadaweel 1, Giza168, and Masr 1) varieties were evaluated under drought stress using different concentrations of polyethylene glycol (PEG) $(0,1,2$, and 3 bars) and investigate the effects of the application of ascorbic acid $(0,150$, and 200 $\mathrm{mg} / \mathrm{L}$ ) in the alleviation of drought stress at the seedling stage. The results revealed that drought stress caused a decrease in germination percentage, growth parameters (shoot length and root length) and photosynthetic pigments (chlorophyll A, chlorophyll B, and total carotenoids) with increasing PEG concentrations in all wheat varieties. Moreover, Catalase (CAT) activity increased in Giza168 with increasing drought stress at 3 bar, whereas CAT activity increased in Masr 1 and a nonsignificant increase in Shandaweel 1 at 1 bar and then decreased at 2 bar. Also, proline accumulation under drought stress in all wheat varieties. On the other hand, pretreatment of seeds treated with ascorbic acid $(0,150,200 \mathrm{mg} / \mathrm{l})$ enhanced all parameters studied under drought stress. $200 \mathrm{mg} / \mathrm{L}$ of ASA is the most effective in mitigating the effects of drought stress on the morphological and chemical characteristics of wheat varieties at the seedling stage.
\end{abstract}

\section{INTRODUCTION}

Drought, one of the environmental stresses, is the most significant factor restricting plant growth and crop productivity in the majority of agricultural fields of the world (Tas and Tas 2007). Drought decreased germination and seedling growth, and this is one important case to produce crops (Gamze et al., 2005). Drought stress causes reduced stomatal conductance resulting in decreased net photosynthetic rate. Chlorophyll degradation due to drought stress also inhibits the photosynthetic rate in wheat (Moaveni, 2011). In addition, it inhibits the photochemical activities and decreases the activities of enzymes in the Calvin Cycle in photosynthesis (Monakhova and Chernyadev 2002). PEG as a factor causing drought stress by reducing water potential results in reducing growth in seed germinated and stopping seedling growth so that this effect has been observed more in the shoot than primary roots (Zhu, 2006). Dodd and Donovan (1999) also suggested that PEG prevents water absorption by seeds, but penetrable ions by reducing 
potential inside cell results in water absorption and starting to germinate. Proline accumulation under salinity/ drought stress (Kavi Kishor et al., 2005), which protect the proteins against denaturation and act as osmotic balancing agents (Sivakumar et al., 2000). The generation of ROS is limited or scavenged by an antioxidant system, including antioxidant compounds (ascorbate, salicylate, glutathione, tocopherol, etc.) and antioxidant enzymes like catalase (CAT), superoxide dismutase (SOD) and peroxidase (POD) (Foyer and Noctor, 2003). Catalase (CAT) and peroxidase (POD) are enzymes that catalyze the conversion of $\mathrm{H}_{2} \mathrm{O}_{2}$ to water and $\mathrm{O}_{2}$ (Gratao et al., 2005).

Wheat (Triticum aestivum L.) is one of the most important crops in Egypt, which plays a special role in people's nutrition. Ninety-five percent of the cultivated wheat is used for the preparation of bread and other baked products, while the remaining $5 \%$ is durum wheat, which is used essentially for making pasta and macaroni (Bushuk, 1998). External application of ascorbic acid activates antioxidant mechanisms, and this improves resistance to drought stress (Shalata and Neumann, 2001). Pre-sowing treatment with ascorbic acid is widely used. It improves performance and stand establishment at different external factors such as high salinity (Shaddad et al. 1990 and Afzal et al. 2005). The objectives of this investigation are to study the effects of ascorbic acid applications as an antioxidant on seeds germination, growth parameters, Photosynthetic pigments, proline, and activity of enzymes in three wheat seedlings grown under drought stress.

\section{Plant material and treatments: -}

\section{MATERIALS AND METHODS}

The present study was carried out in Biochemistry Department, Faculty of Agriculture, Al-Azhar University, three varieties of wheat (Triticum aestivum L.) included Shandaweel 1, Giza168 and Masr 1 were used in this study. wheat seeds were obtained from the Department of Seed Technology Research, Field Crops Research Institute, Agriculture Research Center (ARC), Ministry of Agriculture, Giza, Egypt. Homogeneous seeds were sterilized using $70 \%$ ethanol for $2 \mathrm{~min}$. followed by $0.2 \%$ sodium hypochlorite $(\mathrm{NaOCl})$ for $3 \mathrm{~min}$. then rinsed for 3 times with distilled water.

\section{Application of Ascorbic acid and growth conditions}

After washing the seeds, they were soaked for $24 \mathrm{~h}$ at room temperature in distilled water or 150 and $200 \mathrm{mg} / \mathrm{L}$ Ascorbic acid before sowing in Petri dishes. Effect of drought stress induced by different osmotic potential level $(0,1,2$ and 3 bars) of polyethylene glycol 8000 (PEG 8000) (Michel, 1983). Germination trials were carried out in $15 \mathrm{~cm}$ Petri dishes containing a layer of two filter paper whatman's two filter 
paper sterilized with distilled water or PEG solution. Three replications were sown in Petri dishes on two filter paper beds and each treatment contained 50 pure seeds, then irrigated with $10 \mathrm{ml}$ solution of different concentration of PEG solution (0,1,2 and 3 bars) and incubated in growth chamber at $20 \pm 2{ }^{\circ} \mathrm{C}$ for 10 days. Seed germination was observed daily with fresh PEG solution added to the Petri dishes as necessary to maintain moisture levels. Germination percentage was calculated using the formula outlined by Krishnasamy and Seshu (1990). Seedling shoots and roots lengths of ten randomly selected seedlings were measured after 10 days of germination (ISTA, 1993).

\section{Biochemical analysis: -}

\section{Determination of of photosynthetic pigments:-}

To extract photosynthetic pigment from wheat shoots, $0.2 \mathrm{~g}$ of fresh shoot was homogenized with $10 \mathrm{ml}$ of $100 \%$ acetone in a porcelain mortar and centrifuged at $2500 \mathrm{rpm}$ for $10 \mathrm{~min}$. The supernatant was separated and the absorbances were read at 662 and $645 \mathrm{~nm}$ for chlorophyll $\mathrm{a}$ and $\mathrm{b}$ and $470 \mathrm{~nm}$ for carotene. Were calculated using following equations of Lichtentaler and Wellburn (1985).

Chlorophyll a $(\mu \mathrm{g} / \mathrm{ml})=11.75$ A662 -2.350 A645

Chlorophyll b $(\mu \mathrm{g} / \mathrm{ml})=18.61$ A645 -3.960 A662

Carotenoids $(\mu \mathrm{g} / \mathrm{ml})=1000 \mathrm{~A} 470-2.270 \mathrm{Chl} \mathrm{a}-81.4 \mathrm{Chl} \mathrm{b} / 227$.

\section{Extraction of antioxidant enzymes:-}

Enzymes were extracted from $0.5 \mathrm{~g}$ leaf samples homogenized in a pre-chilled pestle and mortar containing ice cold $0.1 \mathrm{M}$ phosphate buffer $(\mathrm{pH} 7.5)$ and $0.5 \mathrm{mM}$ EDTA. Each homogenate was transferred to centrifuge tubes and centrifuged at $4^{\circ} \mathrm{C}$ in a Sorval model T21 (Thermo Scientific, Waltham, MA) refrigerated centrifuge for $15 \mathrm{~min}$ at $15000 \mathrm{x}$ g. The supernatant was decanted and used for measuring enzyme activity assays (Esfandiari et al., 2007).

\section{Enzymes activity assay:-}

Catalase activity:-

Catalase activity was determined according to the method used by Aebi (1984) in which the disappearance of $\mathrm{H}_{2} \mathrm{O}_{2}$ in a reaction mixture containing $0.3 \mathrm{~mL} 3 \% \mathrm{H}_{2} \mathrm{O}_{2}, 2.5 \mathrm{~mL}$ of $0.05 \mathrm{M}$ phosphate buffer $(\mathrm{pH} 7)$, and $2.5 \mathrm{~mL}$ of plant extract is monitored by the decrease in absorbance at $240 \mathrm{~nm}$.

Peroxidase activity:-

Peroxidase was assayed spectrophotochemically according to (Amako et al., 1994) the assay was carried out at $25^{\circ} \mathrm{C}$ in $1.0 \mathrm{~cm}$ light 
path cuvette and the reaction mixture consisted of $1500 \mu \mathrm{L}$ phosphate buffer, $1000 \mu \mathrm{L}$ pyrogallol and $480 \mu \mathrm{L} \mathrm{H}_{2} \mathrm{O}_{2}$ solution. After mixing, the reaction was initiated by adding the enzyme extract $(20 \mu \mathrm{L})$ and the increase in optical density at $430 \mathrm{~nm}$ against blank (without extract) was continuously recorded every minute (for $1 \mathrm{~min}$ ).

Determination of proline:-

Proline content of shoot was determined according to a modification of the method of Bates et al (1973). Samples of shoots $(0.5$ g) were homogenized in a mortar and pestle with $10 \mathrm{ml}$ sulfosalicylic acid $(3 \% \mathrm{w} / \mathrm{v})$, and then centrifuged at $18,000 \mathrm{~g}$ for $15 \mathrm{~min}$. Two $\mathrm{ml}$ of the supernatant was then added to a test tube, to which $2 \mathrm{ml}$ glacial acetic acid and $2 \mathrm{ml}$ freshly prepared acid ninhydrin solution $(1.25 \mathrm{~g}$ ninhydrin dissolved in $30 \mathrm{ml}$ glacial acetic acid and $20 \mathrm{ml} 6 \mathrm{M}$ phosphoric acid) were added. The test tubes were incubated in a water bath for $1 \mathrm{~h}$ at $100^{\circ} \mathrm{C}$ and then allowed to cool to room temperature. Four $\mathrm{ml}$ of toluene were then added to the tubes and then mixed on a vortex mixer for $20 \mathrm{~s}$. The test tubes were allowed to stand for at least $10 \mathrm{~min}$ to allow separation of the toluene and aqueous phases. The toluene phase was carefully pipetted out into a glass test tube and its absorbance was measured at $520 \mathrm{~nm}$ in a spectrophotometer. The content of proline was calculated from a standard curve and calculated on a fresh weight basis as follows: $\{(\mu \mathrm{g}$ proline $/ \mathrm{ml} \times \mathrm{ml}$ toluene $) / 115.5 \mu \mathrm{g} / \mu \mathrm{mole}\} /\{(\mathrm{g}$ sample $) / 5\}=\mu$ moles proline $/ g$ of fresh weight material.

\section{Statistical analysis:}

Randomized Complete block design analysis for all data obtained was carried out and differences between means were calculated using L.S.D test according to Steel and Torrie (1980).

\section{RESULTS AND DISCUSSION}

The effect of ascorbic acid on germination and growth parameters in three wheat varieties under drought stress by PEG

The effect of ascorbic acid on germination percentage and growth the parameters under drought stress are presented in Table (1). Under control, the highest values of germination percentage were observed in Giza168 and Shandweel 1 (98\%). Germination percentage decreased by increasing of drought stress by PEG level. Germination percentage in all wheat varieties were significantly decreased at 1 and 2 bars but Giza168 has a higher germination percentage (86\%) at 2, while the lowest value of germination percentage was found in Masr 1 variety (56\%) at the same level of drought stress. At 3 bar drought stress germination percentage was $(0 \%)$ in all wheat varieties. From the results in Table (1) indicated that Giza168 more drought tolerant than Shandaweel 1 and Masr 1. 
Table (1): The effect of ascorbic acid on germination and growth parameters in three wheat varieties under drought stress by PEG.

\begin{tabular}{|c|c|c|c|c|c|c|c|c|c|c|}
\hline \multirow{2}{*}{$\begin{array}{l}\text { ASA } \\
\mathrm{mg} / \mathrm{l}\end{array}$} & \multirow{2}{*}{$\begin{array}{l}\text { PEG } \\
\text { bars }\end{array}$} & \multicolumn{3}{|c|}{ Germination \% } & \multicolumn{3}{|c|}{ Shoot length $(\mathrm{cm})$} & \multicolumn{3}{|c|}{ Root length $(\mathrm{cm})$} \\
\hline & & $\begin{array}{c}\begin{array}{c}\text { Shandaw } \\
\text { eel 1 }\end{array} \\
\end{array}$ & Giza168 & Masr 1 & \begin{tabular}{|c|}
$\begin{array}{c}\text { Shandaw } \\
\text { eel 1 }\end{array}$ \\
\end{tabular} & Giza168 & Masr 1 & $\begin{array}{c}\text { Shandaw } \\
\text { eel 1 }\end{array}$ & Giza168 & Masr 1 \\
\hline \multirow{4}{*}{$\mathbf{0}$} & 0 & 98.000 & 98.000 & 92.000 & 11.000 & 11.333 & 10.333 & 10.333 & 10.667 & 8.333 \\
\hline & 1 & 93.000 & 94.000 & 75.000 & 6.000 & 6.333 & 4.667 & 7.667 & 8.000 & 6.000 \\
\hline & 2 & 76.000 & 86.000 & 56.000 & 1.833 & 4.000 & 2.333 & 2.333 & 6.000 & 5.667 \\
\hline & 3 & 0.000 & 0.000 & 0.000 & 0.000 & 0.000 & 0.000 & 0.000 & 0.000 & 0.000 \\
\hline \multirow{4}{*}{150} & $\mathbf{0}$ & 96.000 & 98.000 & 96.000 & 11.333 & 12.000 & 10.333 & 10.667 & 11.333 & 9.000 \\
\hline & 1 & 96.000 & 97.000 & 81.000 & 6.667 & 6.667 & 4.667 & 8.000 & 8.333 & 7.333 \\
\hline & 2 & 81.000 & 91.000 & 53.000 & 2.667 & 4.667 & 3.333 & 5.333 & 7.000 & 5.333 \\
\hline & 3 & 0.000 & 0.000 & 0.000 & 0.000 & 0.000 & 0.000 & 0.000 & 0.000 & 0.000 \\
\hline \multirow{4}{*}{200} & $\mathbf{0}$ & 98.000 & 99.000 & 95.000 & 12.667 & 11.333 & 11.333 & 12.667 & 11.000 & 8.667 \\
\hline & 1 & 95.000 & 98.000 & 83.000 & 10.667 & 8.333 & 10.000 & 8.000 & 8.667 & 7.333 \\
\hline & 2 & 85.000 & 95.000 & 65.000 & 9.000 & 6.667 & 7.333 & 5.667 & 7.333 & 5.667 \\
\hline & 3 & 65.000 & 85.000 & 60.000 & 6.333 & 5.333 & 7.667 & 4.333 & 6.333 & 4.667 \\
\hline $\begin{array}{l}\text { L.S.D } \\
0.05\end{array}$ & & & 2.10 & & & 0.32 & & & 0.88 & \\
\hline
\end{tabular}

Application of ascorbic acid (ASA) as soaking led to increasing of germination percentage in all wheat varieties (Table 1). $150 \mathrm{mg} / \mathrm{L}$ of ASA caused significantly increase in Shandaweel 1 and Giza168 from (76 and $86 \%$ ) to (81 and $92 \%$ ), respectively at 2 bar , while led to decrease in Masr 1 from $56 \%$ to $53 \%$ at 2 bar, $150 \mathrm{mg} / \mathrm{L}$ of ASA was not effective on germination in all wheat varieties at 3 bar. Application of $200 \mathrm{mg} / \mathrm{L}$ of ASA caused increasing of germination in all wheat varieties. Germination percentage increased from $0 \%$ to 65,85 and $60 \%$ at 3 bar in Shandaweel 1, Giza168 and Masr 1, respectively with 200 $\mathrm{mg} / \mathrm{l}$ of ASA. On the other hand, data in Table (1) showed that shoot, root length decreased in all wheat varieties with increasing of drought stress by PEG. The highest values of shoot and root length were found in Giza168 $(11.33 \mathrm{~cm})$ and $(10.66 \mathrm{~cm})$, respectively under normal 
conditions. The lowest values of shoot and root length were observed in Shandaweel $1(1.83 \mathrm{~cm})$ and $(2.33 \mathrm{~cm})$ respectively at 2 bar drought stress. Application of ASA as soaking significantly increased shoot, root length under drought and non-drought. Shoot length in shandaweel1 significantly increased from $6.0 \mathrm{~cm}$ to $6.66 \mathrm{~cm}$ at 1 bar and increased from $1.83 \mathrm{~cm}$ to $2.66 \mathrm{~cm}$ at 2 bar with $150 \mathrm{mg} / \mathrm{L}$ of ASA. Also, $200 \mathrm{mg} / \mathrm{L}$ of ASA significantly increase of shoot length in Giza 168 and Masr 1 from 4.0 and $2.33 \mathrm{~cm}$ to 6.66 and $7.33 \mathrm{~cm}$, respectively at 2 bar. From the results, it is obvious that ascorbic acid pretreatment alleviated the inhibitory effect of drought stress on germination and growth parameters. Also, $200 \mathrm{mg} / \mathrm{L}$ of ASA had higher effect compared to $150 \mathrm{mg} / \mathrm{l}$ of ASA. Increased shoots and root length by ascorbic acid might be due to the cell division and differentiation of meristem cells (Liso et al., 1998). These results agreed with DolatAbadian and Sanavy (2008) reported that priming with ascorbic increased germination percentage, Length of shoot and root, their dry weight, and seedling total dry weight in sunflower.

The effect of ascorbic acid on photosynthetic pigments in shoots of three wheat varieties under drought by PEG

Data presented in Table (2) showed that photosynthetic pigments i.e. chlorophyll a, b and carotenoids were significantly decreased with increasing of drought stress by PEG. chlorophyll a, b and carotenoids of Giza 168 higher than Masr 1 and Shandaweel 1 under drought and control. under control, the maximum values of chlorophyll $\mathrm{a}, \mathrm{b}$ and carotenoids were $0.470,0.394$ and $0.628 \mathrm{mg} / \mathrm{g}$, respectively were found in Giza 168. Drought stress led to significantly decreased chlorophyll a, b and carotenoids in all wheat varieties. The lowest values of chlorophyll a was $0.293 \mathrm{mg} / \mathrm{g}$ in shandaweel 1 , while, the lowest values of chlorophyll $b$ and carotenoids were 0.193 and $0.187 \mathrm{mg} / \mathrm{g}$, respectively in Masr 1 at 2 bar. Application of ASA as soaking led to increase chlorophyll $\mathrm{a}, \mathrm{b}$ and carotenoids contents under drought stress. Chlorophyll a, b and carotenoids of Masr 1 significantly increased from $(0.212,0.194$ and $0.298 \mathrm{mg} / \mathrm{g})$ to $(0.309,0.255$ and $0.389 \mathrm{mg} / \mathrm{g}$ ), respectively with $150 \mathrm{mg} / \mathrm{l}$ of ASA and significantly increased to $(0.388,0.323$ and $0.562 \mathrm{mg} / \mathrm{g})$, respectively with $200 \mathrm{mg} / \mathrm{l}$ of ASA at 1 bar. The highest values of chlorophyll a, b and carotenoids (1.217, 0.842 and $1.079 \mathrm{mg} / \mathrm{g}$ ) were found in Giza 168 with $200 \mathrm{mg} / \mathrm{l}$ of ASA under normal conditions. At 3 bar, the chlorophyll a, b and carotenoids of Giza 168 were higher than Shandaweel 1 and Masr 1 with $200 \mathrm{mg} / \mathrm{L}$ of ASA. From these results showed that Giza 168 had higher chlorophyll a, b and carotenoids under drought stress and $200 \mathrm{mg} / \mathrm{L}$ is the most effective concentration of ASA in reducing the effect of drought stress on total pigment. The decrease of chlorophyll content under water limited condition is reported to take place because of its photo-oxidation and degradation under drought (Anjum et al., 2011). Exogenous application of ascorbic and 
mitigated the adverse effects of drought on photosynthesis in all wheat varieties by increasing stomatal conductance. This could have also been due to the fact that ascorbic acid as an antioxidant has the ability to mitigate the negative effects of stress on plants by neutralizing harmful oxidants which have been reported to damage plant membranes such as the thylakoid membranes of chloroplasts (Dolatabadian et al., 2009). These results agree with Khalil et al. (2010) who found that the application of ascorbic acid in different concentrations showed significant increase in all photosynthetic pigments in Ocimun basilicum plant under water stress. Also, Malik and Ashraf, (2012) found that Ascorbic acid treated seeding of both genotypes maintained higher chlorophyll contents, net- photosynthesis and growthcompared to the non-treated plants.

Table (2): The effect of ascorbic acid on photosynthetic pigments in seedling of three wheat varieties under drought stress by PEG.

\begin{tabular}{|c|c|c|c|c|c|c|c|c|c|c|}
\hline ASA & PEG & \begin{tabular}{|c|} 
Chlorop \\
\end{tabular} & yyll a (m & g F. Wt) & Chlorop & hyll b (m & (g F.Wt) & \begin{tabular}{|c|} 
Caroten \\
\end{tabular} & oids (mg & g F.Wt) \\
\hline $\mathrm{mg} / \mathrm{l}$ & bars & $\begin{array}{c}\text { shandawe } \\
\text { el } 1\end{array}$ & Giza168 & Masr 1 & \begin{tabular}{|c|} 
shandawe \\
el 1
\end{tabular} & Giza168 & Masr 1 & \begin{tabular}{|c|} 
shandawe \\
el 1
\end{tabular} & Giza168 & Masr 1 \\
\hline \multirow{4}{*}{0} & 0 & 0.413 & 0.470 & 0.408 & 0.370 & 0.394 & 0.359 & 0.592 & 0.628 & 0.515 \\
\hline & 1 & 0.358 & 0.366 & 0.212 & 0.199 & 0.244 & 0.194 & 0.348 & 0.386 & 0.298 \\
\hline & 2 & 0.293 & 0.352 & 0.317 & 0.243 & 0.251 & 0.193 & 0.218 & 0.228 & 0.187 \\
\hline & 3 & 0.000 & 0.000 & 0.000 & 0.000 & 0.000 & 0.000 & 0.000 & 0.000 & 0.000 \\
\hline \multirow{4}{*}{150} & 0 & 0.646 & 0.825 & 0.591 & 0.577 & 0.621 & 0.530 & 0.657 & 0.733 & 0.548 \\
\hline & 1 & 0.261 & 0.380 & 0.309 & 0.392 & 0.416 & 0.255 & 0.475 & 0.583 & 0.389 \\
\hline & 2 & 0.188 & 0.268 & 0.163 & 0.193 & 0.224 & 0.102 & 0.217 & 0.271 & 0.176 \\
\hline & 3 & 0.000 & 0.000 & 0.000 & 0.000 & 0.000 & 0.000 & 0.000 & 0.000 & 0.000 \\
\hline \multirow{4}{*}{200} & 0 & 0.937 & 1.217 & 0.829 & 0.566 & 0.842 & 0.309 & 0.862 & 1.079 & 0.650 \\
\hline & 1 & 0.642 & 0.869 & 0.388 & 0.417 & 0.942 & 0.323 & 0.622 & 0.647 & 0.562 \\
\hline & 2 & 0.376 & 0.479 & 0.443 & 0.265 & 0.307 & 0.252 & 0.373 & 0.430 & 0.273 \\
\hline & 3 & 0.226 & 0.232 & 0.192 & 0.195 & 0.204 & 0.148 & 0.106 & 0.128 & 0.094 \\
\hline L.S.D & & & 0.002 & & & 0.30 & & & 0.01 & \\
\hline 0.05 & & & & & & & & & & \\
\hline
\end{tabular}


The effect of ascorbic acid on Catalase, Peroxidase and Proline in seedling of three wheat varieties under drought stress by PEG

Results in Table (3) showed that catalase (CAT) activity significant increase in Giza168 with increasing of drought stress at 3 bar, whereas CAT activity significant increase in Masr 1 and nonsignificant increase in Shandaweel 1 at 1 bar and then decreased at 2 bar. Under control without ASA, the maximum CAT activity was observed in Giza168 (40.33 U/mg F.W) at 2 bar and the minimum CAT activity was found in Masr 1 (29.400 U/mg F.W) under normal conditions. Pretreatment of with $150 \mathrm{mg} / \mathrm{L}$ of ASA caused significant increasing of CAT activity in Masr 1 at all level of drought stress while not effective in Giza168. $200 \mathrm{mg} / \mathrm{L}$ of ASA is the most effective in increase CAT activity as compared to $150 \mathrm{mg} / \mathrm{L}$ (Table 3 ). CAT activity significant increase in Masr 1 from 32.380 to $35.433 \mathrm{U} / \mathrm{mg}$ F.W with $150 \mathrm{mg} / \mathrm{L}$ of ASA and significantly increased to $45.63 \mathrm{U} / \mathrm{mg} \mathrm{F} . W$ with $200 \mathrm{mg} / \mathrm{L}$ of ASA at 2 bar. CAT activity in Shandaweel 1 decreased to $25.53 \mathrm{U} / \mathrm{mg}$ F.W with $150 \mathrm{mg} / \mathrm{L}$ of ASA, while significantly increased to $35.56 \mathrm{U} / \mathrm{mg}$ F.W with $200 \mathrm{mg} / \mathrm{L}$ of ASA at 2 bar.

Also, the results in Table (3) showed that peroxidase (POX) activity significantly increased by increasing of drought stress at 3 bar in all wheat varieties. Under control without ASA, the highest value of POX activity was found in Shandaweel $1(40.33 \mathrm{U} / \mathrm{mg} \mathrm{F.W})$ at 2 bar and the lowest value of POX activity was found in Shandaweel $1(23.36 \mathrm{U} / \mathrm{mg}$ F.W) under normal conditions. Application of ASA as soaking caused significantly increasing of POX activity in all wheat varieties (Table 3). POX activity significantly increased in Giza168 from 30.40 U/mg F.W at 2 bar to $55.33 \mathrm{U} / \mathrm{mg}$ F.W with $150 \mathrm{mg} / \mathrm{L}$ of ASA and increased to 80.63 U/mg F.W with $200 \mathrm{mg} / \mathrm{L}$ of ASA at the same level of drought stress. The maximum POX activity was observed in Shandaweel 1 (93.36 U/mg F.W) and Masr 1 (92.40 U/mg F.W) at 3 bar with $200 \mathrm{mg} / \mathrm{L}$ of ASA. The increased activities of CAT and POX led to limit cellular damage and enhance the plants oxidative capacity to defend stress. CAT and POX activities play a central protective role in the $\mathrm{O}_{2}$ and $\mathrm{H}_{2} \mathrm{O}_{2}$ scavenging process (Hoque et al, 2007). The CAT and POX activity increased under drought stress when compared to control plants. Similar results reported under drought stress in wheat (Shao et al, 2005). These results are similar to that obtained by Rezaei et al. (2013) showed that ascorbic acid led to increasing of catalase, peroxidase activities Dracocephalum moldavica L. under drought stress. 
Table (3): The effect of ascorbic acid on Catalase, Peroxidase and Proline in seedling of three wheat varieties under drought stress by PEG

\begin{tabular}{|c|c|c|c|c|c|c|c|c|c|c|}
\hline ASA & PEG & Catale & ise $(\mathrm{U} / \mathrm{m}$ & F.W) & Peroxi & lase $(U / r$ & gF.W) & Proline & $(\mu \mathrm{moles}$ & g F.W) \\
\hline $\mathrm{mg} / \mathrm{l}$ & bars & $\begin{array}{c}\begin{array}{c}\text { Shandaw } \\
\text { eel 1 }\end{array} \\
\end{array}$ & Giza168 & Masr 1 & $\begin{array}{c}\text { Shandaw } \\
\text { eel 1 }\end{array}$ & Giza168 & Masr 1 & $\begin{array}{c}\begin{array}{c}\text { Shandaw } \\
\text { eel 1 }\end{array} \\
\end{array}$ & Giza168 & Masr 1 \\
\hline \multirow{4}{*}{0} & 0 & 30.590 & 36.433 & 29.400 & 23.367 & 27.317 & 32.367 & 8.250 & 10.220 & 9.330 \\
\hline & 1 & 32.300 & 38.267 & 34.467 & 31.200 & 28.300 & 33.767 & 9.550 & 11.560 & 9.880 \\
\hline & 2 & 29.300 & 40.333 & 32.380 & 40.333 & 30.400 & 36.533 & 10.360 & 13.960 & 12.200 \\
\hline & 3 & 0.000 & 0.000 & 0.000 & 0.000 & 0.000 & 0.000 & 0.000 & 0.000 & 0.000 \\
\hline \multirow{4}{*}{150} & 0 & 32.667 & 38.400 & 30.467 & 40.367 & 44.500 & 35.533 & 10.850 & 12.570 & 10.290 \\
\hline & 1 & 35.467 & 38.700 & 36.567 & 52.400 & 52.300 & 41.333 & 15.600 & 18.960 & 15.690 \\
\hline & 2 & 25.533 & 40.667 & 35.433 & 66.633 & 55.333 & 65.667 & 17.740 & 21.500 & 19.560 \\
\hline & 3 & 0.000 & 0.000 & 0.000 & 0.000 & 0.000 & 0.000 & 0.000 & 0.000 & 0.000 \\
\hline \multirow{4}{*}{200} & 0 & 38.400 & 45.533 & 40.367 & 68.800 & 67.733 & 70.700 & 16.850 & 23.580 & 20.110 \\
\hline & 1 & 42.400 & 44.500 & 44.400 & 52.467 & 77.700 & 67.533 & 18.560 & 26.550 & 21.550 \\
\hline & 2 & 35.567 & 46.667 & 45.633 & 87.667 & 80.633 & 77.500 & 19.710 & 25.890 & 21.630 \\
\hline & 3 & 36.667 & 50.400 & 48.700 & 93.367 & 75.367 & 92.400 & 20.250 & 28.960 & 24.960 \\
\hline L.S.D & & & 2.21 & & & 2.98 & & \multirow{2}{*}{\multicolumn{3}{|c|}{0.98}} \\
\hline 0.05 & & & & & & & & & & \\
\hline
\end{tabular}

On the other hand, drought stress increased the proline contents in all wheat varieties Table (3). Under control without ASA, a maximum increase of proline contents was observed in Giza168 (13.96) mmoles/g at 2 bar. Proline contents in Masr 1 was (12.20) mmoles/g higher than Shandaweel 1 (10.36) mmoles/g at 2 bar. Application of ASA as soaking significantly increased proline contents in all varieties (Table 3). The highest value of proline was found in Giza168 (28.96) mmoles/g at 3 bar with $200 \mathrm{mg} / \mathrm{L}$ of ASA. Application of $200 \mathrm{mg} / \mathrm{L}$ of ASA had higher 
effect compared to $150 \mathrm{mg} / \mathrm{L}$ in increasing of proline contents in all wheat varieties. For example proline contents significantly increased in Shandaweel 1 from 10.36 mmoles $/ g$ at 2 bar to 17.74 mmoles $/ g$ with $150 \mathrm{mg} / \mathrm{L}$ of ASA while increased to $19.71 \mathrm{mmoles} / \mathrm{g}$ with $200 \mathrm{mg} / \mathrm{L}$ of ASA. The role of proline as a protective agent against reactive oxygen species is also very important (Hare et al., 1999). Drought tolerance is positively correlated with high accumulation of proline in many crops like wheat and barley (Nayyar and Walia, 2003). These results agreed with Baghizadeh et al. (2009) who found that proline contents increased with ascorbic acid under drought stress in Okra ( Hibiscus esculentus L.).

\section{REFRENCES}

Aebi, H. (1984): Catalase in vitro. Methods of Enzymology, 105:121126.

Afzal, I. ; S.M.A. Basra ; N. Ahmed and M. Farooq (2005): Optimiz of hormonal priming techniques for alleviation of salinity stress in wheat ( Triticum aestivum L.). Universidade de Santa Cruz do Sul., 17(1):95-109.

Amako, A. ; K. Chen and K. Asada (1994): Separate assays specific for ascorbiate peroxidase and gauiacol peroxidase and for the chloroplast and cytosolic isoenxymese of ascorbate peroxidase in plants. Plant cell physiol., 35:497-504.

Anjum, S.A.; X. Xie ; L. Wang ; M. F. Saleem ; C. Man and W. Lei (2011): Morphological, physiological and biochemical responses of plants to drought stress. African J. Agric. Res., 6: 2026-2032.

Baghizadeh, A.; M. Ghorbanli ; H.M. Rezaei and H. Mozafri (2009): Evaluation of Interaction effect of drought stress with ascorbate and salicylic acid on some of physiological and Biochemical parameters in okra ( Hibiscus esculentus L.). Research Journal of Biological Sciences, 4 (4): 380-387

Bates, L.S.; R.P. Walden and I.D. Teare (1973): Rapid determination of free proline for water-stress studies. Plant Soil, 39: 205-207.

Bushuk, W. (1998): wheat breeding for end-product use Euphytica, carbohydates and $\mathrm{Na}+/ \mathrm{K}+$ changes in two tomato (lycopersicon cell. plant physiol., 85: 529-536.

Dodd, G.L. and L.A. Donovan (1999): Water potential and ionic effects on germination and seedling growth of two cold desert shrubs. Am. J. Bot., 86:1146-1153. 
Dolatabadian, A. and A.M. Sanavay (2008): Effect of the ascorbic acid, pyridoxine and hydrogen peroxide treatments on germination, catalase activity, protein and malonidialdehyde content of three oil seeds. Bot. Hort. Agrobot. Cluj, 36 ( 2 ): $61-66$.

Dolatabadian, A.; A.M. Sanavy and M.S. Harifi (2009): Effect of ascorbic acid (Vitamin C) leaf feeding on antioxidant enzymes activity, proline accumulation and lipid peroxidation of canola (Brassica napus L.) under salt stress condition. Journal of Science and Technology of Agriculture and Natural Resources 13: 611-620.

Esfandiari, E.; M.R. Shakiba ; S. Mahboob ; H. Alyari and M. Toorchi (2007): water stress, antioxidant enzyme activity and lipid peroxidation in wheat seedling. Journal of food Agriculture $\alpha$ Environment, 5:149-153 .

Foyer, C.H. and G. Noctor (2003): Redox sensing and signaling associated with reactive oxygen in chloroplast, peroxisomes and mitochondria . physiol. Plant., 119: 355-364.

Gamze, O.; D.K. Mehmet and A. Mehmet (2005): Effect of salt and drought stresses on germination and seedling growth of pea (Pisum sativum L). Turk. J. Agric., 29: 237-242.

Gratao, P.L.; A. Polle ; P.J. Lea and R.A. Azevedo (2005): Making the life of heavy metal - stressed plants a little easer. Functional plant Biology, 32: 481 -494.

Hare, P.D.; W.A. Cress and J. Van Staden (1999): Proline synthesis and degradation: a model system for elucidating stress-related signal transduction. J. Exp. Bot., 50: 413-434.

Hoque, M.A.; E. Okcma ; M.N.A. Banu ; Y. Nakamura ; Y. Shimoishi and Y. Murata (2007): Exogenous proline mitigates the detrimental effects of salts tressmorethan exogenous betaine by increasing antioxidant enzyme activities, Journal of Plant Physiology, 164: 553-561.

ISTA, (1993): International Seed Testing Association. International Rules For Seed Testing - Seed SCl, and Technol., 21:187-209.

Kavi Kishor, P.B.; S. Sangam ; R. N. Amrutha ; P. Sri Laxmi and K.R. Naidu (2005): Regulation of proline biosynthesis, degradation, up take and transport in higher plants: Its implications in plant growth and abiotic stress tolerance. Curr. Sci., 88: 424-438. 
Khalil, S. E.; N.G. Abd El-Aziz and B. H. Abou Leila (2010): Effect of water stress, ascorbic acid and spraying time on some morphological and biochemical composition of ocimum basilicum plant. Journal of American Science, 6 (12): 33-44.

Krishnasamy, V. and D.V. Seshu (1990): Germination after accelerated ageing and associated characters in rice varieties. Seed Sci. Technol., 18: 147-156.

Lichtenthaler, H.K. and A.R. Wellburn (1985): Determination of total carotenoids and chlorophylls A and B of leaf in different solvents. Biochem. Soc. Trans., 11: 591-592.

Liso, R.G.; A.M. Innocenti ; A. Bitonti and O. Arrigoni (1998): Ascorbic acid-induced progression of quiescent center cells from G1 to S phase, New Phytologist, 110: 469-471.

Malik, S. and M. Ashraf (2012): Exogenous application of ascorbic acid stimulates growth and photosynthesis of wheat (Triticum aestivum L.) under drought. Soil Environ., 31(1):72-77.

Michel, B.E. (1983). Evaluation of the Water Potentials of Solutions of Polyethylene Glycol 8000. Plant Physiol., 72:66-70.

Moaveni, P. (2011): Effect of water deficit stress on some physiological traits of wheat (triticum aestivum). Agricultural science Research Journal, 1:64-68.

Monakhova, O.F. and I.I. Chernyadev (2002): protective role of kartolin-4 in wheat plants exposed to soil drought. Applied and Environmental Microbiology, 38: 373-380.

Nayyar, H. and D.P. Walia (2003): Water stress induced proline accumulation in contrasting wheat genotypes as affected by calcium and abscisic acid. Biol. Plant., 46: 275-279.

Rezaei, H.; G. Mahlagh ; P. Maryam and A. Pazoki (2013): Effect of drought Interactions with Ascorbat on some Biochemical Parameters and Antioxidant Enzymes Activities in Dracocephalum moldavica L. Middle-East J. Sci. Res., 13 (4): 522-531.

Shaddad, M.A ; A.F. Radi ; A.M. Abdel-Rahman and M.M. Azooz (1990): Response of seeds of Lupinus termis and Vicia faba to the interactive effect of salinity and ascorbic acid or pyroxidase. Plant Soil, 122:177-183.

Shalata, A. and P.M. Neumann (2001): Exogenous ascorbic acid (Vitamin C) increase resistance to salt stress and reduces lipid peroxidation. Journal of experimental Botany, 52: 2207-2211. 
Shao, H.B.; Z.S. Liang and M.A. Shao (2005): Changes of antioxidative enzymes and MDA content under soil water deficit among 10 wheat (Triticum aestivum L.) genotypes at maturation stage, Colloid Surf Biointerf, 45: 7-13.

Sivakumar, P .; P. Sharmila and P. Pardha Saradhi (2000): proline alleviates salt stress induced enhancement in ribulose 1,5bisphosphat oxygenase activity. Biochem Biophys. Res Commu., 279:512-515.

Steel, R.G. and J.H. Torrie (1980). Analysis of covariance. Principles and procedures of statistics: A Biometrical Approach, pp.401-437.

Tas, S. and B. Tas (2007): Some physiological responses of drought stress in wheat genotypes with different ploidity in Turkiye. World Journal of Agricultural Science, 3: 178-183.

Zhu, J.K. (2006): Effect of drought stresses induced by polyethylene glycol on germination of pinus Silvestre's var. Mongolica seeds from pollination forests on sandy land. Natural and pollination Forests on sandy Land Journal of Forest Research, 11(5): 319-328.

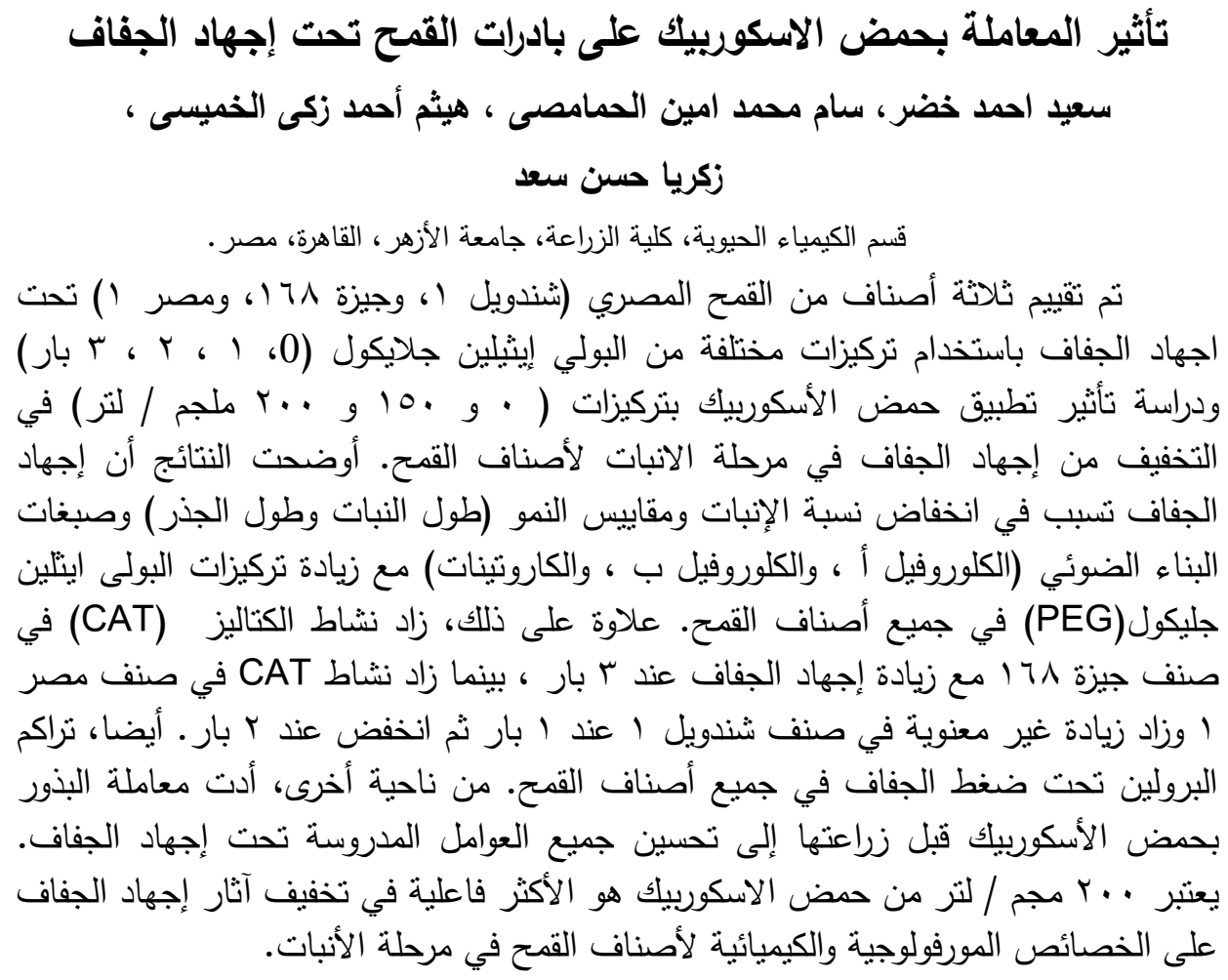

